\title{
Erratum to "Melatonin-Induced PGC-1a Improves Angiogenic Potential of Mesenchymal Stem Cells in Hindlimb Ischemia" [Biomol. Ther. 28 (2020) 240-249]
}

\author{
Jun Hee Lee ${ }^{1,2}$, Yong-Seok Han ${ }^{1}$ and Sang Hun Lee ${ }^{1,2, *}$ \\ ${ }^{1}$ Medical Science Research Institute, Soonchunhyang University Seoul Hospital, Seoul 04401, \\ ${ }^{2}$ Department of Biochemistry, Soonchunhyang University College of Medicine, Cheonan 31538, Republic of Korea
}

After publication of the paper "Melatonin-Induced PGC-1a Improves Angiogenic Potential of Mesenchymal Stem Cells in Hindlimb Ischemia" by Lee et al. (2020), it was noticed that paper contains an error in Fig. 3C. Because of an unintentional error made during the preparation of the results, the authors mistakenly used the unmatched image of Transwell invasion assay. The authors wish to replace the image of Transwell invasion assay in Fig. $3 \mathrm{C}$.

The corrected Fig. $3 \mathrm{C}$ is published here to avoid confusion for readers. The conclusion of the article is unaffected by the error. The authors apologize for this inadvertent error and for any inconvenience caused.

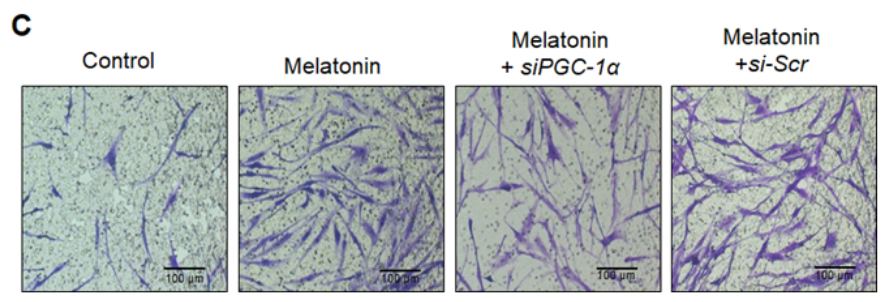

Fig. 3. (C) Transwell invasion assay in MSCs treated with melatonin. Scale bar=100 $\mu \mathrm{m}$.

\section{REFFERENCE}

Lee, J. H., Han, Y. S. and Lee, S. H. (2020) Melatonin-induced PGC-1alpha improves angiogenic potential of mesenchymal stem cells in hindlimb ischemia. Biomol. Ther. (Seoul) 28, 240-249.

\section{Open Access https://doi.org/10.4062/biomolther.2021.454}

This is an Open Access article distributed under the terms of the Creative Commons Attribution Non-Commercial License (http://creativecommons.org/licenses/by-nc/4.0/) which permits unrestricted non-commercial use, distribution, and reproduction in any medium, provided the original work is properly cited.
DOI of original article : https://doi.org/10.4062/biomolther.2019.131

*Corresponding Author

E-mail: ykckss1114@nate.com

Tel: +82-2-709-9029, Fax: +82-2-792-5812 